\title{
A Review Of The Literature On Eco-Design In Manufacturing Industry: Are The Institutions Focusing On The Key Aspects?
}

\author{
María del Val Segarra-Oña, Ph.D., Universidad Politécnica de Valencia, Spain \\ María De-Miguel-Molina, Ph.D., Universidad Politécnica de Valencia, Spain \\ Ana Payá-Martínez, Faurecia, Spain
}

\begin{abstract}
The aim of this paper is to review the most important literature in relation to the special characteristics of the eco design as part of the innovation portfolio of companies.

Eco design is a methodology that takes into account the environmental condition of products from conception. More than a half of the impacts can be prevented from the design process so that throughout their life circle are less harmful to the environment. As a methodology that integrates environmental criteria in the design of products and services, managing the environmental innovation through eco-design has to be considered as part of the strategic definition of both, companies and Public Agencies.
\end{abstract}

We pretend to analyze literature related to eco-design in companies and the way policy makers are pretending to reinforce sustainable attitude at the industrial sector. The main objective of this paper is to uncover if there is any relation between what literature indicates companies are doing and what public administration are pretending with its industrial policies, to see if institutions are focusing on their industrial policies and check if they are covering the key.

Keywords: Eco-Design; Sustainability; Industrial Policy; Competitiveness

\section{INTRODUCTION}

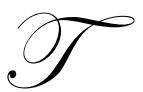

he integration of environmental criteria has to be taken into account when taking decisions during the product development process (Brezet and Van Hemel, 1997, Byggeth and Hochschorner, 2006, FuadLuke, 2009), in the early stages of product development, to achieve the objective of achieving a greater degree of sustainability(Karlsson \& Luttropp, 2006).

The need to promote the application of eco-design through training programs at the enterprise level and through actions carried out by national agencies has been highlighted in the past (Brezet, 1997, Madge, 1997), however, many companies still not assume that eco-design should be part of their daily activity (O'Hare et al., 2010) and should be integrated into their business strategies (Donnelly et al., 2006, Gold et al., 2010). Organizations need to communicate clearly and efficiently to project teams, as well as to senior management, what the company's goal is by including a section devoted to the impact of projects on environment and sustainability (Petala, 2010) and, in the other hand, it is an striking lack of industrial policy actions promoted by the public agencies in that line (Santolaria et al., 2011, Ceschin and Vezzoli, 2010).

This paper reviews the major contributions on the eco-design concept and its actual implementation in the manufacturing industry, following the line of work defined by Sekaran and Boogie (2010), its influence on business competitiveness and actions that, from public agencies, have been implemented to encourage this. 


\section{REVIEW OF THE CONCEPT AND ITS APPLICATION}

As it is actually understood, the aim of the Eco-design is to reduce the environmental impact of products throughout their entire life. For Life Cycle means all life stages of a product, from production of components and raw materials for their production, to disposal of the product once it is discarded, but although this is largely accepted concept both in academic and social level, several definitions are given in the literature, as seen in Table 1.

Table 1. Eco-design definitions

\begin{tabular}{|l|l|}
\hline \multicolumn{1}{|c|}{ Author } & \multicolumn{1}{c|}{ Definition } \\
\hline Alonso (2006) & $\begin{array}{l}\text { Eco design is an approach that integrates environmental criteria in the design of products and } \\
\text { services, so as to get the reduction of environmental impacts they produce, taking into account } \\
\text { all stages of their life cycle. }\end{array}$ \\
\hline Wimmer et al. (2004) & $\begin{array}{l}\text { Eco design is how to integrate environmental considerations into product design and } \\
\text { development. }\end{array}$ \\
\hline Borchardt et al. (2011) & $\begin{array}{l}\text { Eco design is a set of Project practices oriented to the creation of eco-efficient products and } \\
\text { processes. }\end{array}$ \\
\hline Pigosso et al. (2010) & $\begin{array}{l}\text { Eco design is a proactive approach of environmental management that aims to reduce the total } \\
\text { environmental impact of products. }\end{array}$ \\
\hline Plouffe et al., 2011 & $\begin{array}{l}\text { Eco design means taking simultaneously into account the environmental impacts in the } \\
\text { selection of raw materials, the manufacturing process, the storage and transportation phase, } \\
\text { usage, and final disposal. }\end{array}$ \\
\hline Karlsson and Luttropp, 2006 & $\begin{array}{l}\text { Eco design is about Design in and for a sustainable development. } \\
\text { Eco design is understood to be the systematic integration of environmental considerations into } \\
\text { the design process across the product life cycle, from cradle to grave. }\end{array}$ \\
\hline Bhamra, 2004 & $\begin{array}{l}\text { Eco design is a holistic view in that, starting from the moment we know the environmental } \\
\text { problems and its causes, we begin to influence the conception, the materials selection, the } \\
\text { production, the use, the reuse, the recycling and final disposition of industrial products. }\end{array}$ \\
\hline IHOBE, 2011 & $\begin{array}{l}\text { Eco-design means that the environment is taken into account when making decisions during } \\
\text { the product development process as an additional factor that traditionally have been taken into } \\
\text { account. }\end{array}$ \\
\hline
\end{tabular}

Source: Compiled by authors

An innovative definition was made by Karlsson and Luttropp (2006), highlighting the linkages between social, economic, and environmental business in the eco-design linguistic map (see figure 1)

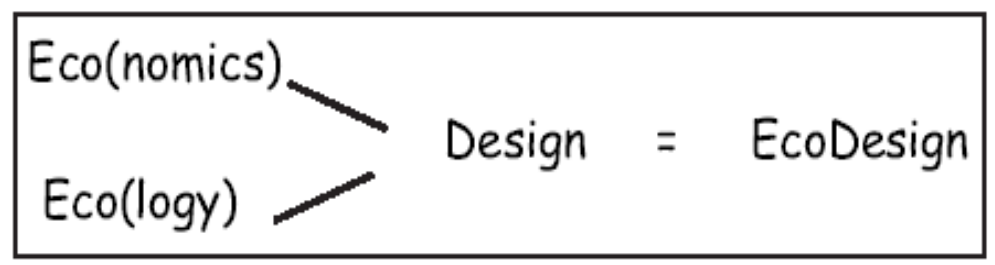

Figure. 1. Linguistic map of “Eco-Design”' (Karlsson and Luttropp, 2006)

Although the concept has been widely studied, actually, the main challenges faced by organizations in the twenty-first century, both the need to develop sustainable products as you generate profits from them and how this affects their competitive position.

\section{ECO DESIGN AND COMPETITIVENESS}

Several authors state competitiveness is a very localized process, based on groups of firms organized around one o several related industries that converge (Porter, 1985, 1998, Grant, 1996, Mintzberg and Lampel, 
1999). Others state that a firm's strategy should be based on its resources and internal capabilities, and that these factors prevail over the market (Grant, 1996).

In accordance with Grant (1996), firms should be competitive basing their strategy on endogenous factors. A firm's capability of response requires deep knowledge about the environment; but also about the management's function and up to which degree the organization's culture affects the firm's profitability and return. A successful use of eco-design tools not only requires the availability of appropriate tools, but also a real integration of eco design within the business operations (Dewulf and Duflou, 2004).

The resources and capabilities approach (Wernerfelt, 1984, Peteraf, 1993, Hamel and Prahalad, 1994) arises as a reinterpretation of the firm's environment, introducing the firm's internal organizational system, as aspects to take into account when considering the causes of a firm's profitability. In this line, Plouffe et al. (2011) disentangle the existing relations among internal aspects related to the company, the eco design concept, understood as a new philosophy and the economic aspects it represents.

Although environmental issues as seen as external to the company as Karlsson and Luttropp, (2006) remark, these two approaches, the external or environmental and the internal one have been focused as different alternatives for the study of the eco design integration, other authors think they complement each other (Dewulf and Duflou, 2004).

The globalisation process of economy has modified the productive activity, enhancing the level of rivalry among firms, which generates an immediate reaction in order to respond successfully to this new situation: the necessity, for the industrial sector in a specific area, to keep a high level of competitiveness, but actually spells out the role played by the environment, the institutions, and the economic policies of a country in the competitive success of some industries, considering environmental proactivity and, indeed, eco design a key differentiating asset (Wimmer et al., 2010). Going behind the product's end-of-life is important to reduce the environmental impact of the product's final disposal and this is actually a key differentiating competitiveness aspect to focus on (Pigosso et al., 2010, Schiavone et al., 2008).

\begin{tabular}{|c|c|c|c|}
\hline $\begin{array}{c}\text { Stage 1 } \\
\text { Viewing Compliance as } \\
\text { Opportunity }\end{array}$ & $\begin{array}{c}\text { Stage 2 } \\
\text { Making Value Chains } \\
\text { Sustainable }\end{array}$ & $\begin{array}{c}\text { Stage 3 } \\
\text { Designing Sustainable } \\
\text { Products and Services }\end{array}$ & $\begin{array}{c}\text { Stage } 4 \\
\text { Developing New Business } \\
\text { Models }\end{array}$ \\
\hline $\begin{array}{l}\text { Central Challenge } \\
\text { To ensure that } \\
\text { compliance with norms } \\
\text { becomes an opportunity } \\
\text { for innovation. } \\
\text { Competencies Needed } \\
\text { - The ability to anticipate } \\
\text { and shape regulations. } \\
\text { - The skill to work with } \\
\text { other companies, } \\
\text { including rivals, to } \\
\text { implement creative } \\
\text { solutions. } \\
\text { Innovation Opportunity } \\
\text { - Using compliance to } \\
\text { induce the company and } \\
\text { its partners to experiment } \\
\text { with sustainable } \\
\text { technologies, materials, } \\
\text { and processes. }\end{array}$ & $\begin{array}{l}\text { Central Challenge } \\
\text { To increase efficiencies } \\
\text { throughout the value chain. } \\
\text { Competencies Needed } \\
\text { - Expertise in techniques such } \\
\text { as carbon management and } \\
\text { life-cycle assessment. } \\
\text { - The ability to redesign } \\
\text { operations to use less energy } \\
\text { and water, produce fewer } \\
\text { emissions, and generate less } \\
\text { waste. } \\
\text { - The capacity to ensure that } \\
\text { suppliers and retailers make } \\
\text { their operations eco-friendly. } \\
\text { Innovation Opportunities } \\
\text { - Developing sustainable } \\
\text { sources of raw materials and } \\
\text { components. } \\
\text { - Increasing the use of clean } \\
\text { energy sources such as wind } \\
\text { and solar power. } \\
\text { - Finding innovative uses for } \\
\text { returned products. }\end{array}$ & $\begin{array}{l}\text { Central Challenge } \\
\text { To develop sustainable } \\
\text { offerings or redesign existing } \\
\text { ones to become eco-friendly. } \\
\text { Competencies Needed } \\
\text { - The skills to know which } \\
\text { products or services are most } \\
\text { unfriendly to the } \\
\text { environment. } \\
\text { - The ability to generate real } \\
\text { public support for sustainable } \\
\text { offerings and not be } \\
\text { considered as "green- } \\
\text { washing." } \\
\text { - The management know- } \\
\text { how to scale both supplies of } \\
\text { green materials and the } \\
\text { manufacture of products. } \\
\text { Innovation Opportunities } \\
\text { - Developing compact and } \\
\text { eco-friendly packaging. }\end{array}$ & $\begin{array}{l}\text { Central Challenge } \\
\text { To find novel ways of delivering } \\
\text { and capturing value, which will } \\
\text { change the basis of competition. } \\
\text { Competencies Needed } \\
\text { - The capacity to understand } \\
\text { what consumers want and to } \\
\text { figure out different ways to meet } \\
\text { those demands. } \\
\text { - The ability to understand how } \\
\text { partners can enhance the value of } \\
\text { offerings. } \\
\text { Innovation Opportunities } \\
\text { - Developing new delivery } \\
\text { technologies that change value- } \\
\text { chain relationships in significant } \\
\text { ways. } \\
\text { - Creating monetization models } \\
\text { that relate to services rather than } \\
\text { products. } \\
\text { - Devising business models that } \\
\text { combine digital and physical } \\
\text { infrastructures. }\end{array}$ \\
\hline
\end{tabular}

Figure. 2. Sustainability Challenges, Competencies, and Opportunities (Nidumolu et al., 2009) 
The definition of competitiveness has been evolving along time. Cohen, Teece, Tyson and Zysman (1984) affirm international competitiveness is based on productivity and, therefore, on an economy's ability to move products towards activities with a higher productivity and a focus on the existing heterogeneity among firms belonging to the same industry. Firms are pools of unique resources and capabilities, which are the basis of competitive advantages (Penrose, 1959, Wernerfelt, 1984, Barney, 1991, Peteraf, 1993), actually , those aspects related to environmental issues, and specially those tied to eco design as cost reduction, new market and new products launches (Borchardt et al., 2011) are becoming key issues that not only depend on business challenges (Nidumolu, 2009), and that affect the opportunities detection and the new business development process (see figure 2), and it is also a society's demand (Hull and Rothenberg, 2008, Auger et al., 2010) and a public statement's (Faber and Frenken, 2010, Juntti et al., 2008, Holzinger et al., 2008).

\section{INDUSTRIAL POLICY AND ECO DESIGN ISSUES}

Even at the media era, we still have to consider that proximity and the informal social net facilitates the transfer of specific; technological knowledge (Aufdretsch y Feldman, 1996, Baptista y Swan, 1998), knowledge about the clients' preferences (Von Hippel, 1988), and about the processes (Helper, 1990, Saxennian, 1996), and that all these variables, actually considering also proactive orientation (Segarra et al., 2011) and eco design (Santolaria et al., 2011) take part in the competitive positioning of a company. , Public environmental policy is able to affect, at least partly; technology, market conditions and the regulatory framework while company internal conditions and aspects are not easily directly influenced by public policy (Rubik, 2001).

Del Río et al. (2010) elaborated an integrated policy framework, including policy features and specific measures that can be implemented to mitigate the barriers to eco-innovations that companies usually face. In their opinion, a combination of environmental and technology policies adapted to the different barriers and characteristics of the technologies could reinforce isolated companies actions.

Considering that, at the academia level, it is argued that policy learning occurs despite, rather than because of the instrumental design of the new assessment procedures, which tends to act as a barrier to open deliberation and knowledge utilisation (Hertin et al., 2009), some industries tend to leader the eco design process at the last decade.

\section{MANUFACTURING INDUSTRIES CASE STUDIES}

Scientific literature has identified several distinctive features about the effect that eco design has on industries. Borchardt et al. (2011) studied the eco design application in the footwear industry in Brazil, using case study. They observed a $10 \%$ cost reduction, the toxic materials were eliminated and also noticed a reduction of energy consumption. In the same type of study, Schiavone et al. (2008) concluded that the automotive industry needs for extended environmental analysis as an information source in order to identify the best-performing design solutions.

O'Hare et al. (2010) found that the electrical and electronic British equipment industry need better suit their needs and that the current understanding of designers requirements for eco-design tools may not be directly applicable. In the same line, Dewulf and Duflou (2004) concluded that sector-wide initiatives can provide incentives for a wider application of eco-design in today's companies.

Other authors that have studied specific aspects of the application of eco design, Platcheck et al., (2008), focuses on the need of having a responsible industrial administration, where all involved in the process will have obligations with the sustainability.

\section{CONCLUSIONS}

This study focused on eco design in manufacturing industry and the needs that companies have when considering the improvement of their environmental performance through eco-design. Benefits from the eco design attitude and implementation have been clearly identify in the literature review, as competitiveness improvements, cost reduction, better company image or new product development, but what several researchers have pointed out is that industry need supporting tools for achieving eco design goals. 
Being eco design an emerging field for both research and practice, which aims to help organizations to obtain better performance, decisions of public authorities are going behind the corporate actions, though the institutions are not Focusing On The Key Aspects.

\section{ACKNOWLEDGEMENTS}

The authors acknowledge the financial aid received from the Spanish Ministry of Science and Innovation through project reference no. EC02008-05895-C02-01/ECON and from the PAID-06-2011 of the Universidad Politécnica the Valencia, that also funded a sabbatical research 2011-2012 course of M. Segarra.

\section{AUTHOR INFORMATION}

María del Val Segarra-Oña, $\mathrm{PhD}$ in Management and Degree in Industrial Engineering by the Universitat Politècnica de València (Spain). Associate Professor in Innovation, Competitiveness, Regional Development and Industrial Policies at the Faculty of Industrial Engineering. Research Interest: The relations between environmental proactivity, eco-innovation and economic performance of companies, applied to industrial and service sectors. Phone +34 963877000-Ext 76844; Fax +34 963877689; E-mail: maseo@omp.upv.es.

María de Miguel Molina, PhD in Management by the Universitat Politècnica de València (UPV) and Law Degree by the Universitat de València. Associate Professor in Public Management and Computers Law \& Ethics at the Faculty of Business Administration and Management and the Computers Engineering School at the UPV (Spain). Director of the Master in Business Administration in International Product and Service Management at the UPV. Research Interest: The relations between regulation and self-regulation in the environmental policies as well in the ICT \& privacy policies. Phone +34 963877000-Ext 76821; Fax +34 963877689; E-mail: mademi@ omp.upv.es.

Ana-María Payá-Martínez, Degree in Industrial Engineering by the Universitat Politécnica de València. Senior thesis performed in the Institut für Maschinenwesen, Technische Universität Clausthal (Germany). Quality, Certification \& Systems / Health, Safety and Environment Manager for US Customers Worldwide \& Iberia \& UK Operations in a Company of the Automotive Industry.

\section{REFERENCES}

1. Alonso García, M. (2006): La Norma de ecodiseño UNE1503001, CONAMA, Congreso Nacional del Medio Ambiente, en Los retos del desarrollo sostenible en España, Madrid.

2. Aufdretsch, D.and Feldman, M. (1996): "R\&D spillovers and the geography of innovation and production" American Economic Review, 86 (3), 630-640.

3. Auger, P., Devinney, T. M., Louviere, J. J. and Burke, P. F. (2010): “The importance of social product attributes in consumer purchasing decisions: A multi-country comparative study. International Business Review, 19 (2), 140-159.

4. Baptista, R. (1998): "Clusters, innovation and growth: a survey of the literature", in Swann, Prevezer y Stout, Ed., The dinamics of industrial clustering. Oxford University Press.

5. Bhamra, T. A. (2004): "Ecodesign: the search for new strategies in product development", J. Engineering Manufacture, 218, 557-569.

6. Borchardt, M., Wendt, M. H., Pereira, G. M. and Sellitto, M. A. (2011): "Redesign of a component based on ecodesign practices: environmental impact and cost reduction achievements", Journal of Cleaner Production, 19, 49-57.

7. Byggeth, S. and Hochschorner, E. (2006): "Handling trade-offs in ecodesign tools for sustainable product development and procurement", Journal of Cleaner Production, 14 (15-16), 1420-1430.

8. Brezet, H. (1997): "Dynamics in ecodesign practice", Industry and environment, 20, (1-2), 21-4.

9. Brezet, H. and Van Hemel, C. (1997): Ecodesign, A promising approach to sustainable production and consumption, UNEP. http://www.unepie.org/ home.html.

10. Ceschin, F. and Vezzoli, C. (2010): "The role of public policy in stimulating radical environmental impact reduction in the automotive sector: the need to focus on product-service system innovation, International Journal of Automotive Technology and Management, 10 (2-3), 321-341. 
11. Del Rio, P., Carrillo-Hermosilla, J. and Konnola, T. (2010): "Policy Strategies to Promote Eco-Innovation”, Journal of Industrial Ecology, 14 (4), 541-557.

12. Dewulf, W. and Duflou, J. R. (2004): "Integrating eco-design into business environments. A multi-level approach", in Talabo, D. and Roche, T. (Eds.), Product Engineering, 55-76. Springer.

13. Donnelly, K., Beckett-Furnell, Z., Traeger, S., Okrasinski, T. and Holman, S. (2006): "Eco-design implemented through a product-based environmental management system", Journal of Cleaner Production, 14, 15-16.

14. Donohue, J.M. and Fox, J.B. (2000): "A multi-method evaluation of journal in the decision and management sciences by US academics", Omega International Journal of Management Science, 28, 17-36.

15. Faber, A., Frenken, K. (2010), "Models in evolutionary economics and environmental policy: Towards an evolutionary environmental economics", Technological Forecasting and Social Change, 76 (4), 462-470.

16. Fuad-Luke, A. (2009): The Eco-Design Handbook: A Complete Sourcebook for the Home and Office, 3rd ed. London: Thames \& Hudson.

17. Gold, S., Seuring, S. and Beske, P. (2010): "Sustainable Supply Chain Management and InterOrganizational Resources: A Literature Review”, Corp. Soc. Responsib. Environ. Mgmt. 17, 230-245.

18. Grant, R. M. (1996): “Toward a knowledge based theory of the firm”. Strategic Management Journal, 17, 109-122.

19. Hamel, G. and Prahalad, C.K., (1.994): "Competing for the future”, Harvard Business Review, 72 84), $122-$ 128.

20. Helper, S. (1990): "Comparative supplier relations in the U.S. and Japanese auto industries: An exit voice approach". Business Economic History, 19, 153-162.

21. Holzinger, K., Knill, C. and Sommerer, T. (2008): "Environmental Policy Convergence: The Impact of International Harmonization, Transnational Communication, and Regulatory Competition, International Organization, 62, 553-587.

22. Hull, C. E. and Rothenberg, S. (2008): "Firm performance: the interactions of corporate social performance with innovation and industry differentiation", Strategic Management Journal, 29, 781-789.

23. IHOBE (2011): Manual práctico de ecodiseño. Operativa de implantación en 7 pasos. Sociedad Pública de Gestión Ambiental. Gobierno Vasco. España

24. Juntti, M., Russel, D. and Turnpenny, J. (2009): "Evidence, politics and power in public policy for the environment", Environmental Science \& Policy, 12, 3, 207-215.

25. Karlsson, R. and Luttropp, C. (2006): "EcoDesign: what's happening? An overview of the subject area of EcoDesign and of the papers in this special issue", Journal of Cleaner Production, 14, 1291-1298.

26. $\quad$ Madge, P. (1997): “Ecological Design: A New Critique”, Design Issues, 13 (2), 44-54.

27. Masera, D. (2003): "Eco-design a Key Factor for Micro and Small Enterprise Development". Proceedings of: Third Internacional Symposium on Environmental Conscious Design and Inverse Manufacturing, Tokyo, Japan.

28. Mintzberg, H. and Lampel, J. (1999): "Reflecting on the strategic process", Sloan Management Review, 40 83), 21-30.

29. Nidumolu, R., Prahalad, C. K. and Rangaswami, M. R. (2009): "Why Sustainability Is Now the Key Driver of Innovation", Harvard Business Review, 87 (9), 56-64.

30. O'Hare, J., Dekoninck, E., McMahon, C. and Turnbull, A. (2010): “Adapting innovation tools to the ecoinnovation requirements of industry: case study results", International Journal of Design Engineering, 3 (2), 172-194.

31. Penrose. E.T. (1959): "The theory of the growth of the firm". New York: John Wiley.

32. Petala, E., Wever, R., Dutilh, C. and Brezet, H. (2010): "The role of new product development briefs in implementing sustainability: A case study", Journal of Engineering and Technology Management, 27 (3-4), 172-182.

33. Peteraf, M. A. (1993): "The cornerstone of competitive advantage: A resource based-view", Strategic Management Journal, 14, 179-191.

34. Pigosso, D., Zanette, E. T., Filho, A. G., Ometto, A. R. and Rozenfeld, H. (2010): "Ecodesign methods focused on remanufacturing", Journal of Cleaner Production 18, 21-31.

35. Platcheck, E.R., Schaeffer, L. Kindlein Jr., W. and Candido, L.H.A., (2008): "Methodology of ecodesign for the development of more sustainable electro-electronic equipments", Journal of Cleaner Production, $16,75-86$. 
36. Plouffe, S., Lanoie, P., Berneman, C. and Vernier, M. F. (2011): "Economic benefits tied to ecodesign", Journal of Cleaner Production, 19 (6-7), 573-579.

37. Porter, M. (1985): “Competitive advantage”, The Free Press, New York, USA.

38. Porter, M. (1998): "Clusters and the new economics of competition", Harvard Business Review, 76 (6), 77 90.

39. Rubik, F. (2001): "Environmental sound product innovation and Integrated Product Policy" The Journal of Sustainable Product Design, 1,: 219-232, 2001

40. Santolaria, M., Oliver-Solà, J., Gasol, C. M., Morales-Pinzón, T. and Rieradevall, J. (2011): "Eco-design in innovation driven companies: perception, predictions and the main drivers of integration. Spanish example”, Journal of Cleaner Production, doi:10.1016/j.jclepro.2011.03.009

41. Saxenian, A. (1996): "Regional advantage: culture and competition in Silicon Valley and Route 128", Cambridge, MA: Harvard University Press.

42. Schiavone, F., Pierini, M., Ecker, V. (2008): "Strategy-based approach to eco-design: an innovative methodology for systematic integration of ecologic/economic considerations into product development process", International Journal of Sustainable Design, 1 (1), 29 - 44.

43. Segarra-Oña, M., Peiró-Signes, A., Albors-Garrigós, J. and Miret-Pastor, L. (2011), "Impact of Innovative Practices in Environmentally Focused Firms: Moderating Factors", Int. J. Environ. Res., 5(2), 425-434.

44. Sekaran, U. and Boggie, R. (2010): Research methods for business. A skill building approach. Ed. Wiley, Chichester, UK.

45. Von Hippel, E. (1988): “The sources of innovation”. Cambridge; Cambridge University Press.

46. Wernerfelt, B. (1984): “A resource - based view of the firm”, Strategic Management Journal, 5, 171-180.

47. Wimmer, W., Züst, R., Kun-Mo, L. (2004): “Ecodesign Implementation. A Systematic Guidance on Integrating Environmental Considerations into Product Development”. Springer, Alliance for Global Sustainability Bookseries, Vol. 6. 


\section{NOTES}

